\title{
PHYSICAL ACTIVITY AMONG PRIMARY SCHOOL CHILDREN AGED 6-10 IN POLAND
}

\section{AKTYWNOŚĆ FIZYCZNA DZIECI W WIEKU 6-10 LAT UCZĘSZCZAJĄCYCH DO SZKÓŁ PODSTAWOWYCH W POLSCE}

\author{
Magdalena Potempa-Jeziorowska ${ }^{1(\mathrm{~A}, \mathrm{~B}, \mathrm{C}, \mathrm{D}, \mathrm{E}, \mathrm{F})}$, Paweł Jonczyk ${ }^{1(\mathrm{~A}, \mathrm{~B}, \mathrm{C}, \mathrm{E})}$, \\ Elżbieta Świętochowska ${ }^{2(\mathrm{C}, \mathrm{D}, \mathrm{E}, \mathrm{F})}$, Marek Kucharzewski ${ }^{1(\mathrm{~A}, \mathrm{D}, \mathrm{E})}$
}

\author{
${ }^{1}$ Department of Descriptive and Topographic Anatomy, Faculty of Medical Sciences in Zabrze, \\ Medical University of Silesia, Katowice, Poland \\ ${ }^{2}$ Department of Medical and Molecular Biology, Faculty of Medical Sciences in Zabrze, \\ Medical University of Silesia, Katowice, Poland
}

Authors' contribution Wkład autorów:

A. Study design/planning zaplanowanie badań B. Data collection/entry zebranie danych

C. Data analysis/statistics dane - analiza i statystyki D. Data interpretation interpretacja danych E. Preparation of manuscript przygotowanie artykułu F. Literature analysis/search wyszukiwanie i analiza literatury G. Funds collection zebranie funduszy

\section{Summary}

Background. Physical activity (PA) is a primary stimulator of human psychosomatic development. Material and methods. The research analysis was based on data for children 6-10 years of age $(n=908)$ attending primary schools in Poland, which were collected through indirect interviews from their parents. The research tool included an anonymous survey questionnaire for which the response rate was $20.8 \%$. A value of $p \leq 0.05$ was taken to indicate statistical significance. Body Mass Index (BMI) was used for the assessment of the weight and height proportions.

Results. Moderate PA of 3-5 hours per week had the highest percentage among girls and boys for type of PA. Moderate to vigorous physical activity (MVPA), which equates to 5-10 hours, was selected by 17.1-28.1\% of girls, depending on body weight, and was most frequent among the group of obese girls. In the group of boys, MVPA=5-10 hours was $17.2-27.6 \%$ respectively, depending on body weight. This answer was most frequently selected by boys with normal body weight $(27.6 \%)$. In the both groups of girls and boys, no statistically significant differences between nutritional status and time spent on PA were noted (girls: $\chi^{2}=24.00 ; p=0.065$; boys: $\chi^{2}=19.33 ; p=0.199$ ). The majority of children surveyed used sports facilities 2-4 times a week. This answer was most frequently chosen by the group of obese boys (51.7\%) and girls $(54.8 \%)$.

Conclusions. Levels of PA among the children in this study was found to be insufficient, and the amount of PA did not have a statistically significant correlation with body weight.

Keywords: excess weight, physical activity, obesity, children

\section{Streszczenie}

Wprowadzenie. Aktywność fizyczna (AF) stanowi podstawowy stymulator rozwoju psychosomatycznego człowieka.

Materiał i metody. Materiał badawczy stanowiły dane na temat dzieci w wieku 6-10 lat (n=908) uczęszczających do szkół podstawowych w Polsce, zebrane drogą wywiadu pośredniego wśród ich rodziców. Narzędziem badawczym był anonimowy kwestionariusz ankiety. Wskaźnik uzyskanych odpowiedzi wyniósł $20,8 \%$. Za poziom istotności statystycznej uznano wartość $p \leq 0,05$. Do oceny proporcji wagowo-wzrostowych badanej grupy zastosowano wskaźnik BMI (ang. Body Mass Index).

Wyniki. Największy odsetek wśród dziewcząt i chłopców stanowiły dzieci podejmujące umiarkowaną AF w ilości 3-5 godzin tygodniowo. Umiarkowaną do intensywnej AF (MVPA), która wynosi 5-10 godzin, wybrało 17,1-28,1\% dziewcząt, zależnie od masy ciała, najczęściej wśród grupy otyłych dziewcząt. W grupie chłopców wskaźnik MVPA=5-10 godzin wyniósł odpowiednio 17,2-27,6\% zależnie od masy ciała. Ta odpowiedź była najchętniej wybierana przez chłopców posiadających prawidłową masę ciała, tj. 27,6\%. Zarówno w grupie dziewcząt jak i chłopców nie odnotowano statystycznie istotnych różnic pomiędzy stanem odżywienia a ilością czasu przeznaczonego na AF (dziewczęta: $\chi^{2}=24,00$; $p=0,065$; chłopcy: $\left.\chi^{2}=19,33 ; p=0,199\right)$. Najwięcej badanych dzieci korzysta $\mathrm{z}$ obiektów sportowych $2-4$ razy w tygodniu. Tę odpowiedź najczęściej wybrała grupa otyłych chłopców $(51,7 \%)$ i dziewczynek $(54,8 \%)$.

Wnioski. Poziom AF badanych dzieci jest niewystarczający, a ilość podejmowanej przez nich AF nie koreluje w sposób istotny statystycznie z ich masą ciała.

Słowa kluczowe: nadwaga, aktywność fizyczna, otyłość, dzieci

Figures: 2

References: 26

Submitted: 2021 Nov 27

Accepted: 2022 Feb 7

Potempa-Jeziorowska M, Jonczyk P, Świętochowska E, Kucharzewski M. Physical activity among primary school children aged 6-10 in Poland. Health Prob Civil. 2022; 16(1): 82-92. https://doi.org/10.5114/hpc.2022.113597

Address for correspondence / Adres korespondencyjny: Magdalena Potempa-Jeziorowska, Department of Descriptive and Topographic Anatomy, Faculty of Medical Sciences in Zabrze, Medical University of Silesia, Katowice, Plac Traugutta 2, 41-800 Zabrze, Poland, e-mail: magdalenapotempa@o2.pl, phone: +48 32 271 72 10 ORCID: Magdalena Potempa-Jeziorowska https://orcid.org/0000-0002-7655-0151, Paweł Jonczyk https://orcid.org/0000-0001-6968-7371

Elżbieta Świętochowska https://orcid.org/0000-0001-5787-7880, Marek Kucharzewski https://orcid.org/0000-0001-7950-679X

Copyright: (C) John Paul II University of Applied Sciences in Biala Podlaska, Magdalena Potempa-Jeziorowska, Paweł Jonczyk, Elżbieta Świętochowska, Marek Kucharzewski. This is an Open Access journal, all articles are distributed under the terms of the Creative Commons Attribution-NonCommercial-ShareAlike 4.0 International (CC BY-NC-SA 4.0) License (http://creativecommons.org/licenses/by-nc-sa/4.0/), allowing third parties to copy and redistribute the material in any medium or format and to remix, transform, and build upon the material, provided the original work is properly cited and states its license. 


\section{Introduction}

Ensuring an adequate amount of physical activity (PA) is an integral part of the proper development of the human body. It constitutes a basic stimulator of psychosomatic development in humans and is vital for maintaining health and reducing the impact of negative lifestyle influences [1]. Regular PA is particularly important from a young age because lasting habits are formed during early childhood development. Through PA, all of the systems in the human body, including locomotor, circulatory, respiratory, immune, nervous, vegetative and endocrine, are developed and strengthened [1].

Adequate levels of PA in the first decades of life increase the chance of its continuation into adulthood. This promotes a longer period of healthy life, delays aging processes and reduces the risk of premature onset of chronic diseases and disabilities. PA also has a significant impact on the body by helping it adapt to changes. This can take form through things like strength conditioning, which helps build resiliency to physical and psychological stimuli. This is done through appropriate gradation of effort, regularity and the diversification of stimuli [2]. The impact of PA on other areas of life and navigating social environments is also important. For example, sport and recreational activities which, in addition to physical benefits, shape social attitudes by teaching young people how to overcome adversity and how to compete. Another desirable effect of regular PA is the building of stamina where the body adapts to increasing physical exertion. PA also increases mental capacity and efficiency [3]. To some, it is also considered as being a part of intelligence. Studies have shown PA to have positive effects on school performance $[4,5]$.

As a result of our increasingly fast-paced lives today, time spent on physical exercise is being reduced in favor of mental work. The so-called physical-mental activity balance, which refers to maintaining homeostasis between physical and mental activity levels, is often overlooked. This has serious consequences and can disrupt psycho-physical development, particularly in children who have not yet developed behavioral patterns and are still learning to function in society. As a result, children are more likely to experience higher levels of tension and anxiety. Aggressive behavior may also occur.

Moreover, undertaking regular PA has a demonstrated role in the treatment of many developmental disorders and diseases. According to the latest recommendations from the World Health Organization (WHO) published in 2020, in order to meet the basic health and developmental needs of children aged 5-17 years, it is recommended that children undertake moderate to vigorous PA (MVPA) lasting an average of 60 minutes every day through activities suited to the developmental stage of the young person. The recommended time can be divided into several shorter time periods, for example, 2 sessions that are each 30 minutes long. This is known as PA accumulation. Compared to the PA recommendations of the WHO from 2010, a modification can be noted as regards the description of the amount of MVPA. The 2010 recommendations mention MVPA of 'at least' 60 minutes daily, while the most recent recommendations use the term 'on average.' In the opinion of the authors of these recommendations, the term 'on average' describes the amount of MVPA much better and makes the data easier to interpret. The WHO also recommends undertaking vigorous physical activity (VPA), which should be performed at least 3 times a week. This can include activities or sports such as basketball, cycling and swimming. The main purpose of VPA is to strengthen bones and muscles [6].

$\mathrm{PA}$ is one of the most important forms of prevention in maintaining a healthy body weight. According to the latest data from the international COSI report assessing the nutritional status of children in European countries, the percentage of children aged 6-9 years in Poland is above the average found in the report. Based on the results, it was found that the problem of excess body weight affects almost $32.4 \%$ of boys and $29.1 \%$ of girls aged 8 years in Poland. This is just above the average prevalence of excess weight among children for all countries in Europe [7]. Unfortunately, the ongoing global pandemic caused by COVID-19 is not helping in the fight against weight disorders. Restrictions and remote learning contribute to the deterioration of eating habits and the significant prevalence of sedentary activities over regular PA.

The aim of this study was to assess PA levels among children 6-10 years of age attending primary schools in Poland. The study also aimed to determine whether there is a correlation between levels of PA and body weight in children in this age group.

\section{Material and methods}

A research survey was administered to children aged 6-10 years attending primary schools in Poland. All information about the children was provided by their parents/legal guardians through the filling in of a questionnaire survey, which was the appropriate research tool for this study. 
Approval for the study was obtained (no. KNW/0022/ KB1/94/I/18/19) from the Bioethics Committee of the Medical University of Silesia, Katowice, Poland. The study was conducted in accordance with the principles of the Declaration of Helsinki. Participation in the study was voluntary and anonymous. Parents provided written consent for their agreeance to participate in the study.

The inclusion criteria for school selected for the study included the consent of the principal of the educational facility and a minimum number of 150 students. The authors' intended to distribute the questionnaires to at least 2 primary schools located in each voivodeship in Poland. A total of 38 schools took part in the study, of which 8 schools were located in the Silesian voivodeship. The questionnaires were given to the children's parents at parent-teacher meetings by the authors of the study, with instructions on how to complete the questionnaire. The questionnaires were filled in during these meetings or at home. Parents who chose to fill in the questionnaire at home handed it back to the child's teacher or directly to the school pedagogue.

The questionnaire was created by the authors of this study while the questions included in it were based on the guidelines created by the Institute of Food and Nutrition in Poland (2017 edition) as contained in the study "Principles of Nutrition for the Polish Population" ("Zasady Żywienia dla populacji Polski") [8]. The questions in the survey were divided into 4 parts. The first part consisted of questions pertaining to anthropometric data (body weight, body height) and basic socio-demographic information of the child's family (family structure, parents' level of education, number of persons working in the family). The next part consisted of questions about children's eating habits, which was the most extensive part of the survey. The third part of the questionnaire included questions about the children's level of PA. The last part was dedicated to parents and was aimed at testing the level of parents' knowledge about the basic principles of proper nutrition.

This paper presents the data obtained from the questionnaire. Stratification was based on the nutritional status of the subjects. A total of 5,000 questionnaires were distributed between September 2018 and March 2019. The response rate was $20.2 \%$. A total of 1,010 questionnaires were received, of which only those with the first part of the questionnaire completely filled in qualified for statistical analysis. Ultimately, data collected from 908 children of similar metric age, with an even split between both sexes, were included in the analysis. The most populous group that participated in the study were boys and girls aged 8 years. The age distribution of the respondents is presented in Table 1.

Table 1. Distribution characteristics of respondents by gender and age

\begin{tabular}{|c|c|c|}
\hline Age (years) & Girls (n) & Boys (n) \\
\hline 6 & 9 & 4 \\
\hline 7 & 104 & 120 \\
\hline 8 & 130 & 119 \\
\hline 9 & 128 & 110 \\
\hline 10 & 99 & $\mathbf{4 3 8}$ \\
\hline Total & $\mathbf{4 7 0}$ & \\
\hline
\end{tabular}

BMI values were calculated based on the basic anthropometric data. Based on the BMIs of the examined children, their protein-energy nutritional status was determined. For this purpose, the international genderand age-specific growth charts, developed in 2007 by the WHO for assessing the nutritional status of children aged 5-19 years, were used. Based on the WHO guidelines, normal body weight is defined as a BMI between the $5^{\text {th }}$ and $85^{\text {th }}$ centile of the respective sex and age. Excess weight is defined as a BMI value falling between the $86^{\text {th }}$ to $95^{\text {th }}$ centile for the appropriate gender and age, while obesity is defined as a BMI above the $95^{\text {th }}$ centile. A BMI below the $5^{\text {th }}$ centile is referred to as being underweight [9].

To determine the recommended level of PA, the MVPA index is used. A value of 7 means engaging in daily moderate PA as recommended, i.e., approximately 60 minutes, 7 days a week.

Analysis of the data was performed using the statistical software IBM SPSS Statistics, version 25 . For comparative analysis of the data, the parametric Student's $t$-test for independent variables and the nonparametric Mann-Whitney and Kruskal-Wallis U-tests were used. Correlation analysis was performed using Pearson's $r$ and Spearman's rho coefficients. A value $p \leq 0.05$ was considered statistically significant. 


\section{Results}

\section{Nutritional status}

Approximately $75 \%$ of the participants (76.1\% girls and $73.2 \%$ boys) were found to have a normal body weight. Excessive weight was more common among boys than girls -7.5\% of girls and $13.3 \%$ of boys were overweight while being underweight was more characteristic of girls. The prevalence of obesity among the group of girls and boys was similar. More girls (2.5\% more) than boys were underweight (Table 2).

Table 2. Distribution of nutritional status by gender

\begin{tabular}{|l|c|c|c|c|c|c|c|c|}
\hline & \multicolumn{2}{|c|}{ Underweight } & \multicolumn{2}{c|}{ Normal body weight } & \multicolumn{2}{c|}{ Overweight } & \multicolumn{2}{c|}{ Obese } \\
\cline { 2 - 9 } & $\mathbf{n}$ & $\mathbf{\%}$ & $\mathbf{n}$ & $\mathbf{\%}$ & $\mathbf{n}$ & $\mathbf{\%}$ & $\mathbf{n}$ & \% \\
\hline Girls & 44 & 9.4 & 357 & 76.1 & 35 & 7.5 & 33 & 7.0 \\
\hline Boys & 30 & 6.9 & 320 & 73.2 & 58 & 13.3 & 29 & 6.6 \\
\hline
\end{tabular}

Comparing the study group with respect to age, the groups of 6-, 8-, and 9-year-old children had the greatest numbers with normal body weight. Excessive weight was most common among 7- and 10-year-olds. The highest number of obese children was recorded among 7-year-olds. The detailed distribution of nutritional status by age is shown in Table 3.

Table. 3. Distribution of nutritional status by age

\begin{tabular}{|c|c|c|c|c|c|c|c|c|}
\hline \multirow{2}{*}{$\begin{array}{c}\text { Age } \\
\text { [years] }\end{array}$} & \multicolumn{2}{|c|}{ Underweight } & \multicolumn{2}{c|}{ Normal body weight } & \multicolumn{2}{c|}{ Overweight } & \multicolumn{2}{c|}{ Obesity } \\
\cline { 2 - 9 } & $\mathbf{0}$ & $\mathbf{n}$ & $\mathbf{\%}$ & $\mathbf{n}$ & $\mathbf{\%}$ & $\mathbf{n}$ & $\mathbf{\%}$ & $\mathbf{n}$ \\
\hline 6 & 0.0 & 0 & 91.6 & 11 & 8.4 & 3 & 0.0 & 0 \\
\hline 7 & 10.6 & 20 & 69.8 & 132 & 11.1 & 21 & 8.5 & 16 \\
\hline 8 & 5.2 & 13 & 80.4 & 201 & 8.4 & 21 & 6 & 15 \\
\hline 9 & 4.0 & 10 & 78.6 & 194 & 9.7 & 24 & 7.7 & 19 \\
\hline 10 & 8.2 & 17 & 75.1 & 157 & 10.1 & 21 & 6.6 & 14 \\
\hline
\end{tabular}

\section{Level of physical activity}

The results of the PA assessment are presented separately in subgroups divided by gender and nutritional status. For preferred leisure activities, most respondents indicated outdoor activities. This response applied to half of the overweight girls and $67.7 \%, 61.5 \%$ and $65.4 \%$ of the underweight, normal weight and obese girls respectively. In the group of overweight and obese girls, the percentage of respondents indicating that they spend their leisure time passively (25.0 and $23.1 \%$ respectively) was higher than in the underweight and normal weight groups (16.1 and $17.6 \%$, respectively) (Table 4).

Table 4. Leisure activities — responses by gender and nutritional status

\begin{tabular}{|c|c|c|c|c|c|c|c|c|}
\hline & \multicolumn{4}{|c|}{ Girls [\%] } & \multicolumn{4}{c|}{ Boys [\%] } \\
\cline { 2 - 9 } & $\begin{array}{c}\text { Under- } \\
\text { weight }\end{array}$ & $\begin{array}{c}\text { Normal } \\
\text { body weight }\end{array}$ & $\begin{array}{c}\text { Over- } \\
\text { weight }\end{array}$ & Obese & $\begin{array}{c}\text { Under- } \\
\text { weight }\end{array}$ & $\begin{array}{c}\text { Normal } \\
\text { body weight }\end{array}$ & $\begin{array}{c}\text { Over- } \\
\text { weight }\end{array}$ & Obese \\
\hline $\begin{array}{c}\text { Regular participation } \\
\text { in sport }\end{array}$ & 16.1 & 21.0 & 25.0 & 11.5 & 22.7 & 28.8 & 27.1 & 23.8 \\
\hline Outdoor activity & 67.7 & 61.5 & 50.0 & 65.4 & 54.5 & 49.4 & 54.2 & 42.9 \\
\hline Passive leisure & 16.1 & 17.6 & 25.0 & 231 & 22.7 & 21.9 & 18.8 & 33.3 \\
\hline
\end{tabular}

However, the differences between the groups were not statistically significant $\left(\chi^{2}=3.64 ; p=0.725\right)$. A similar distribution of results was observed among boys. Most of them, regardless of body weight, indicated that they preferred to spend their free time outdoors. This answer was chosen by about half of the respondents in each group, except for the obese boys' group, in which only $42.9 \%$ of boys declared their preference for this form of leisure activity. This group also had the highest percentage of boys who preferred passive leisure (33.3\%). Obese 
boys are also the only group among boys in which the percentage of children who chose passive leisure as a form of free time activity is higher than the percentage of children who chose regular sport. The majority of boys who regularly participate in sports were of normal weight (28.8\%) and overweight (27.1\%) (Table 4). However, these observations were not statistically significant. The study did not demonstrate a statistically significant relationship between the nutritional status of boys and their preferred leisure activities $\left(\chi^{2}=2.34 ; p=0.886\right)$.

In addition, the questionnaire included a question about whether the child also participates in various forms of PA together with his or her parent(s). Among girls, the results indicate that the highest percentage of active time spent with parent(s) was found among overweight girls, while the lowest was among obese children. The results suggest that the girls' subgroups do not differ in this respect $\left(\chi^{2}=3.30 ; p=0.347\right)$. Among boys, the responses were as follows: more than half of underweight, normal weight and obese boys $(62.1 \%, 55.8 \%, 65.5 \%$, respectively) do not engage in PA with their parent(s). However, overweight boys were more likely to undertake it (Table 5).

Table 5. Engaging in PA with a parent - distribution of responses by gender and nutritional status

\begin{tabular}{|c|c|c|c|c|c|c|c|c|}
\hline & \multicolumn{4}{|c|}{ Girls [\%] } & \multicolumn{4}{c|}{ Boys [\%] } \\
\cline { 2 - 10 } & $\begin{array}{c}\text { Under- } \\
\text { weight }\end{array}$ & $\begin{array}{c}\text { Normal body } \\
\text { weight }\end{array}$ & $\begin{array}{c}\text { Over- } \\
\text { weight }\end{array}$ & Obese & $\begin{array}{c}\text { Under- } \\
\text { weight }\end{array}$ & $\begin{array}{c}\text { Normal body } \\
\text { weight }\end{array}$ & $\begin{array}{c}\text { Over- } \\
\text { weight }\end{array}$ & Obese \\
\hline Yes & 32.6 & 38.9 & 42.9 & 25.0 & 37.9 & 44.2 & 51.7 & 34.5 \\
\hline No & 67.4 & 61.1 & 57.1 & 75.0 & 62.1 & 55.8 & 48.3 & 65.5 \\
\hline
\end{tabular}

However, the differences between groups in this respect were found to be statistically insignificant $\left(\chi^{2}=2.90\right.$; $p=0.407)$. The next question analyzed from the questionnaire concerned the number of hours per week that the child devoted to PA. The response options were: a) none; b) less than 3 hours; c) 3-5 hours; d) 5-10 hours; e) 10-15 hours; f) more than 15 hours. Options a), b) and c) were considered to be insufficient PA and option d) corresponded roughly to the recommended PA. Responses e) and f) corresponded to VPA. The results show that the highest proportion of children in each study group, both among girls and boys, were those undertaking 3-5 hours of PA per week (MVPA=3-5). Among the girls surveyed, 38.6-43.5\% selected MVPA, depending on their body weight. The optimal amount is 5-10 hours of PA per week (MVPA=5-10), which was chosen by 17.1$28.1 \%$ of the girls surveyed, depending on their nutritional status. Interestingly, the group of obese girls chose this answer most often (28.1\%), compared to girls from other groups. Among boys, the option MVPA=5-10 was most frequently chosen by boys with normal body weight (27.6\%). The option of 3-5 hours per week was most frequently chosen by overweight boys (55.2\%). The lowest response rate among underweight, normal weight and overweight girls and boys was for options indicating that the child did not devote any time to PA (the "none" option). However, among obese girls and boys this answer was not the least chosen, as it was selected by 6.3 and $6.9 \%$ respectively. Moreover, it can be seen from the results that none of the obese girls perform more than 15 hours of PA per week. The results are presented in Figures 1 and 2.

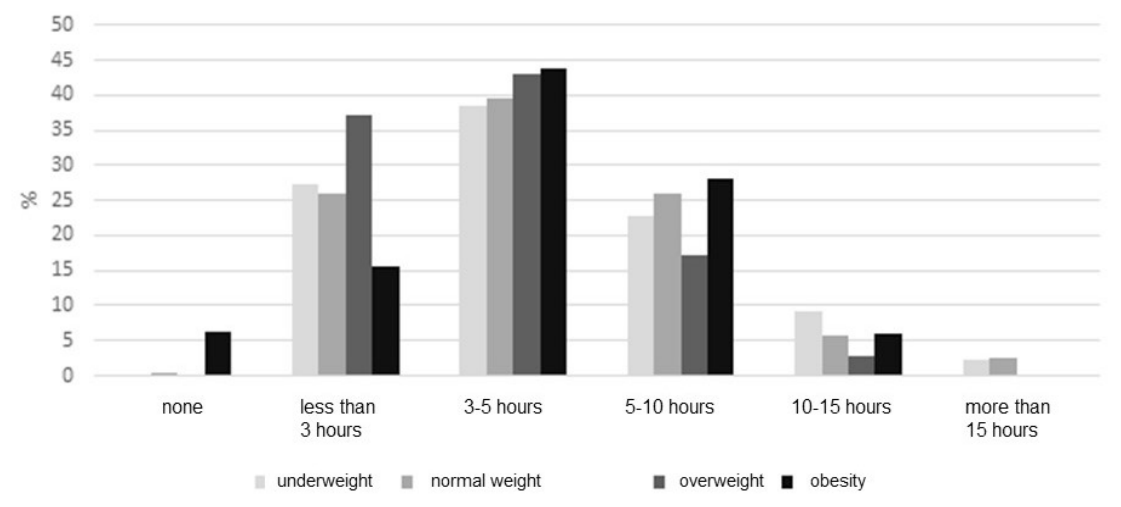

Figure 1. Number of hours per week spent on PA among girls

Notes: Stratification based on nutritional status. 


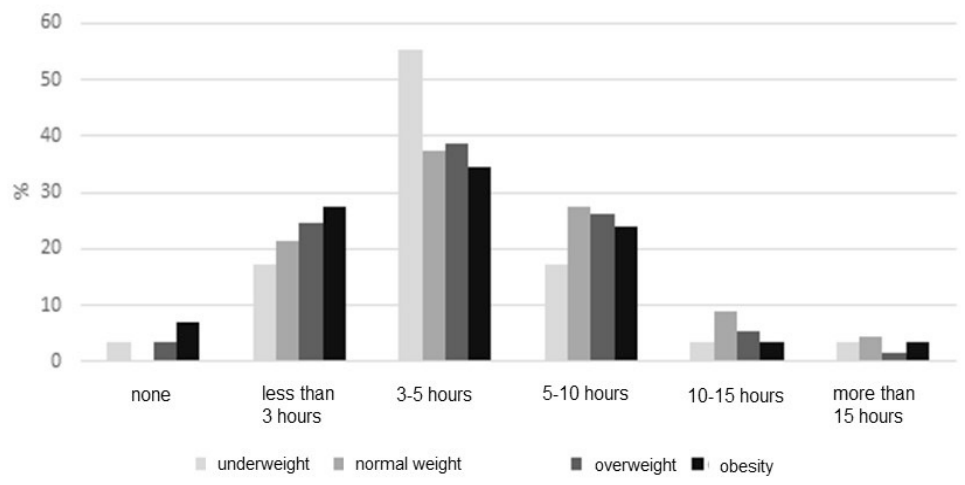

Figure 2. Number of hours per week spent on PA among boys

Notes: Stratification based on nutritional status.

Neither in the group of girls nor boys were there statistically significant differences between nutritional status and the amount of time spent on PA $\left(\chi^{2}=24.00 ; p=0.065\right.$ for girls and $\chi^{2}=19.33 ; p=0.199$ for boys). Parents were also asked how many times per week their child uses sports facilities like swimming pools, sports halls or sports fields. Based on the results presented in Table 4, the same number of underweight girls use sports facilities either once a week or 2-4 times a week (39.5\%). Importantly, in the case of overweight and obese girls, more than half went to such places $2-4$ times per week (52.9\% and 54.8\%, respectively) (Table 6).

Table 6. Frequency of using sports facilities per week

\begin{tabular}{|c|c|c|c|c|c|c|c|c|}
\hline & \multicolumn{4}{|c|}{ Girls [\%] } & \multicolumn{4}{c|}{ Boys [\%] } \\
\cline { 2 - 10 } & $\begin{array}{c}\text { Under- } \\
\text { weight }\end{array}$ & $\begin{array}{c}\text { Normal body } \\
\text { weight }\end{array}$ & $\begin{array}{c}\text { Over- } \\
\text { weight }\end{array}$ & Obese & $\begin{array}{c}\text { Under- } \\
\text { weight }\end{array}$ & $\begin{array}{c}\text { Normal body } \\
\text { weight }\end{array}$ & $\begin{array}{c}\text { Over- } \\
\text { weight }\end{array}$ & Obese \\
\hline 5-7 times & 2.3 & 4.9 & 2.9 & 0.0 & 10.0 & 6.6 & 6.9 & 0.0 \\
\hline 2-4 times & 39.5 & 43.3 & 52.9 & 54.8 & 43.3 & 48.8 & 46.6 & 51.7 \\
\hline 1 time & 39.5 & 36.1 & 29.4 & 32.3 & 26.7 & 33.9 & 36.2 & 27.6 \\
\hline Does not use & 18.6 & 15.8 & 14.7 & 12.9 & 20.0 & 10.8 & 10.3 & 20.7 \\
\hline
\end{tabular}

Notes: Distribution of responses by gender and nutritional status of the children surveyed.

However, there were no significant differences between groups among girls with respect to the frequency of using sports facilities $\left(\chi^{2}=4.91 ; p=0.842\right)$. Analyses of data among boys showed that the highest percentage of boys in each group use sports facilities 2-4 times a week. At the same time, as many as $1 / 5$ of obese boys do not use sports facilities at all (Table 6). As in the case of girls, there were no statistically significant differences between the subgroups of boys (subgroups based on body weight) with respect to frequency of use of sports facilities $\left(\chi^{2}=7.58 ; p=0.557\right)$.

\section{Discussion}

"Physical activity is able to replace almost every medication, but all medications taken together cannot replace physical activity", is a statement from Dr. Wojciech Oczko that although seems to be largely forgotten, is quite relevant in today's times [10]. Lifestyle choices constitute the decisions and actions that have the greatest impact on our health. According to the health field concept established in the 1970s by the Canadian Minister of Health, Marc Lalonde, lifestyle is responsible for about $55 \%$ of our health [11]. It is much more than the environment we live in, genetic factors or access to modern health care. Importantly, lifestyle is the area we can control more than anything else. Adequate levels of PA should be of prime importance in this regard.

In 2013, a report prepared by the Institute of Mother and Child (IMiD), commissioned by the (then) Minister of Sport and Tourism in Poland, was published to assess PA levels among school children and adolescents 9-17 years of age. The study included 3,346 school children 10-17 years of age living throughout Poland and involved a questionnaire survey as the research tool. The study was conducted in schools, using the auditory method. To assess levels of PA, the indicators recommended by the WHO were used, e.g., MVPA and VPA. The results of the study showed that most school children and adolescents do not meet the WHO recommendations regarding 
minimum levels of PA. The report indicated that only $1 / 5$ of the children surveyed $(28.5 \%$ of boys and $15.2 \%$ of girls) aged 9-17 years reached the moderate to vigorous PA criterion (MVPA), which is a minimum of 60 minutes daily. Moreover, this percentage decreased with age, from $28.4 \%$ at age $11-12$ to $13.5 \%$ at age $15-17$. The critical period of rapid decline in PA is at age 12 for girls and 14 for boys, which can be linked to the period of puberty. The VPA criterion, on the other hand, was met by $35.7 \%$ of the adolescents surveyed. Only 1 in 8 respondents (13.3\%) met both criteria at the same time. The survey also included information on the amount of passive recreation, which requires low energy expenditure. According to the results, young people spent on average 2.5 hours per day watching films and 1.6 hours per day playing computer games. According to the report, these types of activities increased on weekends. The report also included an analysis of the factors that show the strongest association with PA among schoolchildren. These included health-oriented motivation for PA and social contacts. In terms of individual considerations, it was observed that the criteria for recommended MVPA were met more frequently in adolescents with normal nutritional status. In addition, attention was paid to a positive self-image as a result of PA. So-called contextual determinants were also among the factors that determined PA; these included family affluence, engaging in PA with parents and parents' perception of PA, general social support in the family and clarity of communication in the family [12].

In 2018, a new edition of this report was published. In contrast to the previous one, the latest report also analyzed the PA levels starting with pre-school children, i.e., from the child's 3rd birthday until adulthood (in the previous report, the age range was 9-17 years). Data from a total of 11,685 children and adolescents was analyzed. Information on PA for younger children was provided by parents and from age 11 onwards by the children and teenagers themselves. The results of this report revealed that among 8-year-olds, almost 2/3 of the children surveyed participated in organized physical activities. Boys participated in these types of activities significantly more often than girls and devoted more time to them, specifically an average of 3.76 hours per week, while the largest group of boys participating in physical activities exercised 3-5 hours per week (54.3\%). Girls spent on average 3.11 hours on PA and the highest percentage (48.2\%) was recorded among girls who exercised 1-2 hours per week. The report also took into account where the surveyed children lived in regard to undertaking regular PA. The results demonstrated that children living in urban areas are more likely to participate in organized physical activities than children living in rural areas (66.6\% vs. 56.1\%). It is interesting to note that almost $83 \%$ of 8-year-old children undertook PA for 1 hour or more on school days, while during weekends this value increased by $10 \%$. This meant that the MVPA 7 among the children studied was $83 \%$. This value is very optimistic and is in strong contrast to the results obtained in our study. However, as the experts in this report point out, how the question is phrased in the report does not correspond to the criterion of MVPA in children and adolescents, and the results obtained are overestimated. In this question; however, the distribution of responses by place of living is different from that in the previously cited question, i.e., there is a large predominance of children living in rural areas who devote at least 1 hour or more per day to PA [13]. Unfortunately, our study did not include an analysis of PA in relation to where children live. Our analysis included the nutritional status of the participants, which was not included in the report by the IMiD.

According to data from a 2016 study by the Central Statistical Office of Poland (GUS) on PA levels among Poles, $18 \%$ of children aged 10-14 years and 29\% of young people aged 15-19 years did not participate in sports and recreational activities. In addition, $27 \%$ of children and $28 \%$ of adolescents indicated that they have no interest or desire to participate in sports and recreational activities or that they prefer passive leisure [14]. When interpreting sports and recreational activities as a form of regular participation in sport, the data compiled by the GUS are similar to our results regarding the percentage of girls who regularly participate in sports in their free time. Importantly, in our study, it was boys who were more likely to practice sport in their free time than girls, and the percentages attributed to them are actually higher than those found by the GUS.

A valuable scientific source on PA among schoolchildren is the periodically published HBSC (Health Behavior in School-Aged Children) survey reports, which monitors and analyzes the health and health-related behavior of schoolchildren aged 11, 13 and 15. The scope of these investigations is international. They are carried out within the framework of the HBSC research networks and are intended to gain an understanding of the factors influencing the health of young people with a particular focus on social contexts, including the home environment, school, place of residence, family status and wealth. Poland has been regularly participating in this project for 25 years. PA is measured in HBSC studies using the test developed by Prochaska et al. using the MVPA index [15]. As indicated by the results from the HBSC survey conducted in 2014, the recommended PA time, defined as MVPA=7, was reported in $24.2 \%$ of the adolescents surveyed, which is less than $1 / 4$ of the population surveyed. The largest percentage of children, about $1 / 3$ of the subjects, had an MVPA=3-4 (27.9\%) and MVPA=5-6 (27.4\%). The PA of adolescents was decreasing with age and was lower among girls than among boys. In 15-year-olds, the percentage of those complying with international recommendations on PA was only $17.8 \%$. At the same 
time, according to the HBSC survey, 1 in 10 boys aged 15 and 1 in 5 girls reported almost no PA (MVPAs1). According to this study, the most important factors determining the amount of PA included place of residence. It was demonstrated that the small city environment was conducive to meeting PA level recommendations, while in large cities, these indicators were least favorable. The study also revealed a statistically significant positive relationship between family wealth and recommended levels of PA. On the other hand, family structure has not been shown to determine PA levels in a statistically significant way. However, the study found that the smallest number of children meeting the requirements for adequate levels of PA were in reconstructed families [16]. Compared to the most recent HBSC survey report from 2018, a clear negative trend was found, as the percentage of adolescents meeting WHO recommendations for moderate PA decreased from $24.2 \%$ in 2014 to only $17.2 \%$ in 2018 [17].

The latest WHO report presents aggregated data from the HBSC report published in 2018 and compares it to data in the previous edition of the survey (in 2014). The results are evident - in every age group, i.e., among 11-, 13-, and 15-year-olds, there was a significant decrease in MVPA as well as VPA in 2018 compared to 2014. At the same time, the data on Polish children in this sphere are well below the average among the 43 countries participating in the survey [18]. The authors of this study look forward to the next HBSC report that will have results for 2021-2022, which will in some way reflect the impact of the COVID-19 pandemic on young people.

A study by Zawadzka et al. published in 2015 involved self-assessment of physical fitness levels and vitality among Polish adolescents, which included analysis of the relationship between these parameters and PA. Almost 3,000 students took part in the study. Data from two age groups were analyzed: younger and older pupils 13-14 years of age $(n=1,531)$ and those $15-17$ years of age $(n=1,388)$. An anonymous questionnaire was used, including a question about MVPA, self-assessment of physical fitness and willingness to improve it and a shortened vitality scale according to the concept of Ryan and Frederick. The vitality scale included three statements: "I am full of energy," "I look forward to each new day" and "I almost always feel ready for action" [19]. The respondent's task was to assess, on a 5-grade scale, to what extent he or she agreed with these statements. The results indicated that in the entire group studied, the criterion of MVPA=7 days was met by $18.3 \%$ of the respondents with a statistically significant predominance of boys (25.4\% vs. $11.8 \% ; p<0.001)$. Taking into account the age groups, the 13- to 14-year-old group was significantly more likely to have MVPA=7 than the group of 15- to 17-year-olds (21.7\% vs. 14.5\%; $p<0.001)$. Participants' perceptions of physical fitness and vital energy had trends of change similar to the MVPA index. Having an awareness or feeling that improving physical fitness is very important was found to be the main factor in increasing the chance of adolescents meeting the MVPA criterion for recommended PA. After this, the percentage of MVPA increases almost 2-fold among adolescents who consider themselves to be very fit, who consider improved fitness to be very important and who have high levels of vitality. This was more important for boys than for girls. Among girls, PA levels were more dependent on age and vitality levels [20].

In a report by Dąbrowska et al., a qualitative assessment of physical fitness among children and adolescents aged 11-15 years living in rural areas was performed. For this purpose, a fitness test, Krzysztof Zuchora's Index of Physical Fitness, was used. The test uses 6 elements that include tests of jumping ability, flexibility, speed, arm strength, abdominal muscular strength and endurance. The results of the survey could be deemed satisfactory. They showed that children and adolescents' fitness was at a relatively good level. From among the elements of the Physical Fitness Index, the abdominal strength test scored the lowest. On the other hand, respondents demonstrated very good flexibility, endurance and speed. The test results did not differ with respect to the gender of the respondents. However, the oldest group of subjects, aged 15, received the lowest scores on the fitness test. The study also used a survey questionnaire on PA and healthy lifestyles, which was completed by the students surveyed. Most respondents evaluated their PA as good (43.05\%) or very good (37.97\%). No one rated their fitness level as very low. The next question aimed at determining whether there were reasons that would prevent the students from being physically active, and to provide some examples of such reasons. Of the respondents, $75.95 \%$ answered that there were no reasons preventing them from being physically active. However, nearly one quarter of the students (24.05\%) reported that there were reasons, with the most frequently cited one being a lack of motivation and health status. In addition, almost $70 \%$ of the students (68.35\%) declared that they take care of their health. More than half of the respondents (67.09\%) declared that they were satisfied with the appearance of their body. An assessment of leisure time activities showed that the students preferred active leisure [21]. Our study also revealed similar results, with children choosing outdoor exercise as their preferred leisure activity.

Another interesting study compared PA levels between normal and overweight children aged 11-12 years. The study also used a questionnaire survey as its research tool for evaluating PA and the Zuchora's test was used to assess physical fitness levels. The analysis included nutritional status. The results revealed that there was a statistically significant decrease in physical fitness with an increase in BMI. Moreover, a higher level of PA 
positively correlated with an active form of leisure [22]. However, these relationships were not demonstrated in our study, as no statistically significant correlation was found between PA levels and nutritional status.

Another study demonstrated that only $1 / 3$ of the children surveyed devoted their free time to PA, including sports activities, and the predominant answer chosen by almost $42 \%$ of the respondents was passive leisure like computer games. The interval estimation performed showed that, from the marked confidence intervals, there is no statistically significant difference in the number of children spending their free time in varied ways. Analysis of participation in physical education (PE) classes, the results of this study showed that $1 / 5$ of children attended PE classes once a week or did not attend at all. Half of the respondents participated in these classes 2 times a week and $28 \%$ of the children followed the school schedule of 3 times a week ( 3 or 4 lessons). In this case, an interval estimation was also performed. It showed that the number of children who exercised 2 times a week was significantly higher than those who exercised once a week, and similar to the group that exercised 3 times a week [23].

Unfortunately, our questionnaire did not include a separate question on PE classes, therefore, it is difficult for the authors to make a comparative reference to the aforementioned report. Nevertheless, the authors draw attention to the very important topic of participation in PE classes, pointing out the existing tendency to skip them deliberately and without medical justification, as well as the consequences of remote studying. One of the reasons for this is the global pandemic caused by COVID-19. During the last 2 years, PA has been significantly undermined by the restrictions imposed due to the pandemic. As a result of social isolation and the shutdown of educational facilities, a deterioration in the health behaviors of children can be expected in areas such as PA.

A recent report by Bronikowska et al. showed how the lockdown introduced in Poland affected PA levels among adolescents in relation to WHO recommendations. This study was comparative; that is, it assessed PA levels before (early March 2020) and after (end June 2020) the initial period of lockdown using an online survey questionnaire. The results show that before lockdown, the majority of subjects (76\%), did not meet the WHO criteria for MVPA. The study showed that among this group of adolescents, about $13 \%$ had a significant increase in PA after the lockdown period - before lockdown, the MVPA was 2.9 days/week and after lockdown it increased to 5.4 days/week ( $p=0.01)$. However, the majority of the respondents (86.6\%) did not change their PA habits after the lockdown. In the group that met WHO recommendations before lockdown ( $25 \%$ of adolescents), the distribution of PA levels afterwards is as follows: half of the adolescents continued the recommended level of PA, but the other half were significantly less physically active than before lockdown. The authors of this study believe that these results confirm the negative impact of the pandemic on children's engagement in PA [24].

Another interesting study by Tulchin-Francis et al. examined the impact of the pandemic and associated restrictions on health behavior among children in the United States. The study took place between April and June 2020, during the initial lockdown. The study also used an online questionnaire that was completed by parents of children aged 3-18 years. A total of 1,310 questionnaires were collected in the study. Parents were asked about their child's participation in organized sports and recreational activities, PA in their backyards, neighborhood or organized by third parties both before the pandemic and in the last 7 days during the lockdown. The survey also included a question about their child's participation in educational activities with low energy expenditure (art, writing and activities using electronic devices) both before the pandemic and 7 days before completing the survey. In addition, the survey included a question about parents' PA. Analysis of the results showed that children's PA decreased during the pandemic. PA rate before the pandemic was estimated to be $56.6 \%$ and decreased to $44.6 \%$ after the lockdown. In particular, MVPA decreased from 46.7 to 34.7 (max. 98; $p<0.001)$. The lowest impact on health behavior with respect to PA was observed in preschool children and the highest in secondary school students (-4.7 vs. $-17.2 ; p<0.001)$ [25].

An interesting initiative aimed at setting new rules for organizing group sports activities for children was set up in 2020 in the state of Missouri in the United States. In consultation with the health organization SSM Health and medical experts, recommendations were made on how to organize sports and recreational activities for children and adolescents "anew," in view of the ongoing pandemic. The study distinguished 4 phases of a return to organized sports and team activities while maintaining safety rules during the COVID-19 pandemic [26]. The results of the study are comparable to the results in our study.

The authors of this report feel that the advantage of their study is the large study group. This means that the results may, to a large extent, reflect the actual level of PA among Polish children. Unfortunately, the study did not demonstrate a statistically significant relationship between PA levels and frequency of sports facility use with the nutritional status of the children studied. However, there are discernible tendencies among some responses, such as the frequent use of sports facilities by obese boys and girls and that obese girls undertake PA at the recommended level (MVPA=5-10) more frequently than others groups. 
At the same time, it should be noted that our study did not include an assessment of physical fitness. Such an assessment, if carried out even among a smaller number of subjects, could be a valuable addition to the extensive survey data obtained in this study. In addition, the questionnaire lacked information on the inclusion of PA time performed as part of PE classes in relation to weekly PA scores, which could slightly modify the data. In the opinion of the authors, the survey also lacks a question on the frequency of PA during the weekend, when, by definition, children and their parents have more free time. Furthermore, the study was conducted before the COVID-19 pandemic and the ensuing restrictions. Unfortunately, when looking at other cited reports, it can be assumed that a change in the epidemiological situation in Poland may contribute to a decrease in the percentage of children regularly undertaking PA. Another limitation of the study may lie in the survey questionnaire that was used as the primary research tool used. While surveys are an easily accessible and employable research tool for the researcher, it must be kept in mind that their results are not always fully factual. This includes data on basic anthropometric parameters, which were reported by parents and not measured by the authors of the study. Moreover, the low response rate may indicate that parents are not sufficiently interested in this topic, despite its importance.

\section{Conclusions}

The results of the study indicate that PA levels are insufficient among both young girls and boys. Not enough children devote the recommended amount of time to daily and weekly PA. By design, the survey in this study was intended to determine PA levels in a somewhat approximate manner. Nonetheless, the results provide valuable information to pediatricians and family medicine physicians about activity levels among children. The findings should encourage doctors to take more action and talk to their patients about lifestyle medicine and the principles of prevention of weight disorders. A good opportunity to do this is during a child's routine health check-up during which the physician can speak with both the child and their parent(s). However, in everyday medical practice, it is quite common to encounter both children who do not engage in any PA at all (apart from PE classes) and those who participate in daily, very intensive PA. For young people, the parent is an important role model (sometimes the only one) who, by his or her own choices around PA, can instill in the child the desire for regular exercise. There is still need for more detailed research on this topic, taking into account, for example, children's participation in PE classes as well as physical activities during free time like weekends.

\section{Disclosures and acknowledgements}

The authors declare no potential conflicts of interest with respect to the research, authorship, and/or publication of this article. This work was funded by the authors.

The authors of this study would like to express their sincere thanks to all those involved in carrying out this study, especially the principals of the primary schools for their consent to conduct the study and for their welcoming attitude towards it.

\section{References:}

1. Kruk J. Physical activity and health. Asian Pacific J Cancer Prev. 2009; 10 (5): 721-728.

2. Piggin J. What is physical activity? A holistic definition for teachers, researchers and policy makers. Front. Sports Act. Living. 2020; 72(2): 1-7. https://doi.org/10.3389/fspor.2020.00072

3. World Health Organization. The challenge - keep moving. In: Steps to health. A European framework to promote physical activity for health. Geneva: World Health Organization; 2007. p. 5-9.

4. Bartholomew JB, Jowers EM. Physically active academic lessons in elementary children. Prev Med. 2011; 52(Suppl. 1): S51-4. https://doi.org/10.1016/j.ypmed.2011.01.017

5. Kibbe DL, Hackett J, Hurley M, McFarland A, Schubert KG, Schultz A, et al. Ten Years of TAKE 10!®: Integrating physical activity with academic concepts in elementary school classrooms. Prev Med. 2011; 52(Suppl. 1): S43-50. https://doi.org/10.1016/j.ypmed.2011.01.025

6. Bull FC, Al-Ansari SS, Biddle S, Borodulin K, Buman MP, Cardon G, et al. World Health Organization 2020 guidelines on physical activity and sedentary behaviour. Br J Sports Med. 2020; 54: 1451-1462. https://doi. org/10.1136/bjsports-2020-102955

7. World Health Organization. Overweight and obesity. In: WHO European Childhood Obesity Surveillance Initiative (COSI): report on the fourth round of data collection, 2015-2017. Copenhagen: WHO Regional Office for Europe; 2021. 
8. Jarosz M., editor. [Dietary guidelines for Poles]. Warszawa: Instytut Żywności i Żywienia; 2017 (in Polish).

9. de Onis M, Onyango AW, Borghi E, Siyam A, Nishida C, Siekmann J. Development of a WHO growth reference for school-aged children and adolescents. Bull World Health Organ. 2007; 85: 660-667. https://doi. org/10.2471/BLT.07.043497

10. Starczyńska M, Karwacińska J, Stepanek-Finda B, Kiebzak W. [Historical background of physiotherapy]. Studia Medyczne. 2011; 21: 71-77 (in Polish).

11. Lalonde M. A new perspective on the health of Canadians. Ottawa, ON: Minister of Supply and Services Canada; 1974.

12. Mazur J. [Areas of physical activity of children and youth]. In: Mazur J., editor. [Physical activity of schoolchildren aged 9-17. Current indicators, tendencies in their changes, and selected external and internal conditioning. Final report. Part I: quantitative research]. Warszawa: Instytut Matki i Dziecka; 2013 (in Polish).

13. Jodkowska M, Korzycka M. [Physical activity of early school-age children in the light of COSI 2016 research]. In: Fijałkowska A., editor. [Current assessment of the physical activity level of children and youth aged 3-19 in Poland]. Warszawa: Ministerstwo Sportu i Turystyki; 2018. p. 78-89 (in Polish).

14. Łysoń P. [Participation in sports and physical recreation in 2016]. Warszawa: Główny Urząd Statystyczny; 2017 (in Polish).

15. Prochaska JJ, Sallis JF, Long B. A physical activity screening measure for use with adolescents in primary care. Arch Pediatr Adolesc Med. 2001; 155(5): 554-559. https://doi.org/10.1001/archpedi.155.5.554

16. Nałęcz H. [Health behaviors. Physical activity]. In: Mazur J., editor. [Health and health behavior of schoolchildren in Poland in the context of the selected sociodemographic determinants. HBSC 2014 research results]. Warszawa: Instytut Matki i Dziecka; 2015. p. 119-125 (in Polish).

17. Kleszczewska D, Dzielska A. [Health behaviors. Physical activity of the youth]. In: Mazur J, MałkowskaSzkutnik A., editors. [Health of students in 2018 in the context of the new HBSC research model]. Warszawa: Instytut Matki i Dziecka; 2018. p. 87-92 (in Polish).

18. Inchley J, Currie D, Budisavljevic S, Torsheim T, Jåstad A, Cosma A, et al., editors. Spotlight on adolescent health and well-being. Findings from the 2017/2018 Health Behaviour in School-aged Children (HBSC) survey in Europe and Canada. International report. Volume 2. Key data. Copenhagen: WHO Regional Office for Europe; 2020.

19. Ryan RM, Frederick C. On energy, personality and health: subjective vitality as a dynamic reflection of wellbeing. J Personal. 1997, 65(3): 529-565. https://doi.org/10.1111/j.1467-6494.1997.tb00326.x

20. Zawadzka D, Mazur J, Oblacińska A. [Self-assessment of physical fitness and vitality versus physical activity in schoolchildren]. Probl Hig Epidemiol. 2015; 96(1): 149-156 (in Polish).

21. Dąbrowska K, Cybulski M, Konopka A, Krajewska-Kułak E. [Physical fitness of rural children and adolescents on the example of Polish pupils from the School Complex in Ołdaki]. Pediatr Med Rodz. 2017; 13 (4): $527-539$ (in Polish). https://doi.org/10.15557/PiMR.2017.0056

22. Kubusiak-Słonina A, Grzegorczyk J, Mazur A. [The assessment of fitness and physical activity in school children with excessive and normal weight]. Endokrynologia, Otyłość i Zaburzenia Przemiany Materii. 2012; 8(1): 16-23 (in Polish).

23. Pitucha A, Metera A. [Characteristics of eating habits and physical activity in the early school-aged child in the Góra Puławska]. Zeszyty Naukowe Wssp. 2013; 17: 67-85 (in Polish).

24. Bronikowska M, Krzysztoszek J, Łopatka M, Ludwiczak M, Pluta B. Comparison of physical activity levels in youths before and during a pandemic lockdown. Int J Environ Res Public Health. 2021; 18(10): 5139. https://doi.org/10.3390/ijerph18105139

25. Tulchin-Francis K, Stevens W Jr, Gu X, Zhang T, Roberts H, Keller J, et al. The impact of the coronavirus disease 2019 pandemic on physical activity in U.S. children. J Sport Health Sci. 2021; 10(3): 323-332. https://doi.org/10.1016/j.jshs.2021.02.005

26. Mahaffey BL. COVID-19 Guidelines for sports and physical activity. Mo Med. 2020; 117(3): 205-206. 